Research Article

\title{
The Effect of Non-Seasonal Climate Variations on Extreme Rainfall Events in Early Rainy Season Onset in Southest West Java Province
}

\author{
Agus Safril 1,a, Hadi Saputra ${ }^{2, b, *}$, Siswanto ${ }^{3,4, c}$, Aulia Nisa'ul Khoir ${ }^{3, d}$, \\ and Aditya Kusuma Al Arif ${ }^{2, e}$ \\ ${ }^{1}$ Sekolah Tinggi Meteorologi Klimatologi dan Geofisika \\ Jl. Perhubungan I No 5 Pondok Betung, Tangerang Selatan, Banten \\ ${ }^{2}$ Stasiun Klimatologi Bogor \\ Jl. Raya Darmaga KM 6.5 Bogor \\ ${ }^{3}$ Badan Meteorologi Klimatologi dan Geofisika \\ Jl. Angkasa I No 2, Jakarta Pusat, DKI Jakarta \\ ${ }^{4}$ Institute for Environment Studies, Vrije Universiteit Amsterdam, The Netherlands \\ De Boelelaan 1105, 1081 HV Amsterdam Netherlands \\ e-mail: ${ }^{\mathrm{a}}$ agus.safril@ @stmkg.ac.id, ${ }^{\mathrm{b}}$ hadi.saputra@ gmail.com, ${ }^{\mathrm{c}}$ siswanto@ @bmkg.go.id, ${ }^{\mathrm{d}}$ khoirneko@gmail.com, \\ and ${ }^{\mathrm{e}}$ adityakuncaramuda@gmail.com \\ * Corresponding Author
}

\begin{abstract}
The region of Tasikmalaya, Garut, and Pangandaran (hereafter mentioned as Southeast West Java Province) experienced extreme precipitation that occurred on September 16, 2016, October 6, 2017, and November 5, 2018, which then followed by flood. The characteristics of these extreme rainfall events need to be communicated to the related disaster management agency and the local citizens as a part of understanding the risks and disaster mitigation. This paper aims to determine the relation between extreme rainfall and non-seasonal climate variations such as Madden Julian Oscillation (MJO), El Niño Southern Oscillation (ENSO), tropical storm, and local circulation that occur simultaneously. Atmosphere and ocean data, including daily rainfall, precipitable water, cloud satellite imagery, wind and sea surface temperature were used. Descriptive statistical analysis, atmospheric dynamics, and physical atmosphere were applied to characterize the event, spatially and temporally. The results showed that the MJO was a non-seasonal factor that always exists in these three early rainy season extreme rainfall events in the region. Other non-seasonal factors such as interaction between La Nina and tropical disturbance; La Nina and local circulation; and El Nino and local circulation also affected the extreme rainfall events. We conclude that the intra-seasonal climate variation of MJO and inter-annual climate anomaly of La Nina/ El Nino, tropical storm, and local circulation are among the weather generators for extreme rainfall during early rainy season (September to November) in the Southeast West Java Province.
\end{abstract} Keywords: non-seasonal climate variation; extreme rainfall; MJO; ENSO; local circulation 
Jurnal Penelitian Fisika dan Aplikasinya (JPFA), 2020; 10(2): 173-187

\title{
Pengaruh Variasi Iklim Non-Musiman terhadap Hujan Lebat pada Awal Musim Hujan di Wilayah Jawa Barat Bagian Tenggara
}

\begin{abstract}
Abstrak
Wilayah Tasikmalaya, Garut, dan Pangandaran (selanjutnya disebut Provinsi Jawa Barat bagian Tenggara) mengalami curah hujan ekstrem yang terjadi pada 16 September 2016, 6 Oktober 2017, dan 5 November 2018, yang kemudian diikuti oleh peristiwa banjir. Karakteristik dari kejadian curah hujan ekstrem ini perlu dikomunikasikan kepada lembaga manajemen bencana dan masyarakat terkait sebagai bagian dari memahami risiko dan mitigasi bencana. Makalah ini bertujuan untuk mengetahui hubungan antara curah hujan ekstrem dan variasi iklim non-musiman seperti Madden Julian Oscillation (MJO), El Niño Southern Oscillation (ENSO), badai tropis, dan sirkulasi lokal yang terjadi secara bersamaan. Data atmosfer dan lautan, diantaranya curah hujan harian, air mampu curah, citra satelit awan, angin dan suhu permukaan laut telah digunakan. Analisis statistik deskriptif, dinamika atmosfer, dan atmosfer fisik diterapkan untuk mengkarakterisasi peristiwa tersebut secara spasial dan temporal. Hasil penelitian menunjukkan bahwa MJO adalah faktor non-musiman yang selalu ada dalam tiga kejadian hujan ekstrim awal musim hujan di wilayah ini. Faktor non-musiman lainnya seperti interaksi antara La Nina dan gangguan tropis, La Nina dan sirkulasi lokal, dan antara El Nino dan sirkulasi lokal juga menyertai peristiwa curah hujan ekstrem. Kami menyimpulkan bahwa variasi iklim intra-musiman MJO dan anomali iklim antar-tahunan La Nina / El Nino, badai tropis, dan sirkulasi lokal adalah di antara pemicu hujan ekstrim pada awal musim hujan (September hingga November) di bagian tenggara Provinsi Jawa Barat.
\end{abstract}

Kata Kunci: variasi non musiman; hujan ekstrem; MJO; ENSO; sirkulasi lokal

PACS: 92.05.Df; 92.30.La; 92.40.E-

(C) 2020 Jurnal Penelitian Fisika dan Aplikasinya (JPFA). This work is licensed under CC BY-NC 4.0

Article History: Received: September 14, 2019

Revised (Round 1): January 16, 2020

Accepted: September 21, 2020
Decided to resubmit (Round 1): December 10, 2019

Approved with minor revision: March 17, 2020

Published: December 31, 2020

How to cite: Safril A, et al. The Effect of Non-Seasonal Climate Variations on Extreme Rainfall Events in Early Rainy Season Onset in Southest West Java Province. Jurnal Penelitian Fisika dan Aplikasinya (JPFA). 2020; 10(2): 173-187. DOI: https://doi.org/10.26740/jpfa.v10n2.p173-187.

\section{INTRODUCTION}

The Southeast regions of West Java (Tasikmalaya, Garut, and Pangandaran) are agricultural areas and one of the rice barns in West Java [1]. The rice production of these regions often suffered from floods caused by extreme rainfall or drought due to a prolonged dry season. Such natural disasters also damage agricultural land especially rice fields [2]. The characteristics of extreme events need to be communicated to the related disaster management agency as well as the local citizens as part of risk understanding and disaster mitigation.
Extreme rainfall, as one of the natural extreme events in the tropical area generally occurs when there are supercell convective clouds (or sometimes multicell) due to an anomalous large scale or local atmospheric features, or often due to the interaction between both. Over Java island, the anomalous large scale features that created highly amount rainfall events often indicated by an intensified monsoon with the northerly component penetrating more to the south than usual [3], the higher humidity and the increased convective activity. The anomalous humidity up to $20 \%$ more than 
the climatology fueled strong convection in the area enclosed by west Borneo, Java Sea, South Sumatera, and West Java [4].

An intensified Asian monsoon often followed by the convergence of air masses from the northern (Asian monsoon) and southern (Australian monsoon) hemisphere namely the Inter-Tropical Convergence Zone (ITCZ) [5]. ITCZ resulting in cumulonimbus clouds that produce rainfall with heavy intensity, reaching more than 100 millimeters/day. Vertical motion of water vapor during ITCZ events may reach a maximum rate [6]. This ITCZ event usually occurs during the rainy season, generally from January to February over Java Island [7]. Java Island has a type of monsoonal rainfall with peak rainfall in the DJF (December-January-February) period [8,9]. The month in which indicated as the peak of the rainy season is marked by the dominance of zonal barriers with a high accumulated convective rain [10].

Beside the ITCZ as one of the variability of Australasian monsoonal system, in the different space and time scale, other phenomenon are believed to also cause extreme rainfall, such as Meso-scale Convective Complex (MCCS) [11], the MJO (Madden Julian Oscillation), La Nina as wet phase of El Nino Southern Oscillation (ENSO), negative phase of Indian Ocean Dipole Mode (IOD), and tropical cyclone or atmospheric disturbances such as tropical storms [12].

The MJO is a propagated large convective cloud cluster from Indian Ocean toward Pacific Ocean via the Maritime Continent regions with a 30-60 days cycle. MJO explains the increase in meso-scale cloud variance (meso-scale convective system) between $11 \%$ - 29\% [13]. La Nina and IOD are also generating convective clouds more pronounced over Indonesia regions, but within the inter-annual time scale between 2 - 8 years variability.

The weather or climate event that arises is not singular, i.e. monsoonal patterns are influenced by non-seasonal systems like ENSO [14,15]. For example, the characteristics of ITCZ do not change in its patterns when they get global influences, for example of ENSO and IOD, but it tends to shift in time [16]. Meanwhile, the propagation of the MJO over Indonesia may strengthen (weaken) the rainy season associated with the wet (dry) phase of the MJO, while it is considered that wet (dry) phase also increases (reduces) rainy days during dry season. Another non-seasonal system that should be acknowledged is the local circulation [17] such as mountain-valley wind and land-sea breeze, which influences the temporal characteristics of the event.

As the Australasian monsoonal system is the dominant feature of Indonesia rainfall, precipitation extreme mostly occurred at the peak of the rainy season (December January - February, DJF) [8,9] caused by ITCZ [10]. In this research, we focus on exploring the characteristics of precipitation extreme during the transition time from dry to rainy season or earlier rainy season (September - October - November, SON). We assume that, since Asian monsoon as the rainy season regulator is not active yet, the extremity of precipitation will be dominantly affected by non-seasonal factors. We will look at the influence of ENSO (El Nino/La Nina), MJO, tropical storm and local circulation.

The purpose of this study is to find the non-seasonal variation causes of heavy rainfall events in the early rainy season onset in particular, the MJO, La Nina, atmospheric disturbance, and local circulation (due to topography) which occur simultaneously in the Southeast region of West Java.

\section{METHOD Data}

Rainfall data used for the analysis of extreme rainfall events are daily rainfall data from Automatic Rain Gauge (ARG) and measured rainfall from conventional instruments from the Bogor Climatological Station as shown in Figure 1. To obtain rainfall patterns in space and time, we use ten days accumulated rainfall (the so called operationally as "dasarian") data from 8 rainfall stations in the southern part of West 
Java. This analysis is to describe the pattern of the rainy and dry seasons.

The analysis of streamline $(850 \mathrm{hPa})$ and dew point $(700 \mathrm{hPa})$ were used to describe [18]. Additionally, MJO index from Bureau Meteorology of Australia was also obtained to analyze the seasonal oscillations of rainfall [19]. We used the Precipitable Water (PW) data, sea level temperature, and wind direction and speed produced by the National Center Prediction (NCEP) [20]. To look at the ENSO pattern, we used the Nino 3.4 Index data from NOAA [21].

Three hourly satellite imageries on September $16^{\text {th }}, 2016$; October $6^{\text {th }}, 2017$; and November $5^{\text {th }}, 2018$ were taken on the surrounding West Java region to analyze the growth, mature, and decay processes of the clouds. The period times are hourly sequence of cloud growth every three hours on the $5^{\text {th }}$ to $6^{\text {th }}$ of June at 06:00 UTC (13:00 Local Time) until 00:00 UTC (07.00 Local Time). Satellite imagery from Kochii University, Japan [22] was also retrieved to give better understanding.

\section{Data Analysis}

Temporal analysis for seasonal and nonseasonal carried out with regional climatological analysis to obtain information on the start of the rainy season, and the process of extreme rainfall events on an hourly time scale (Figure 1).

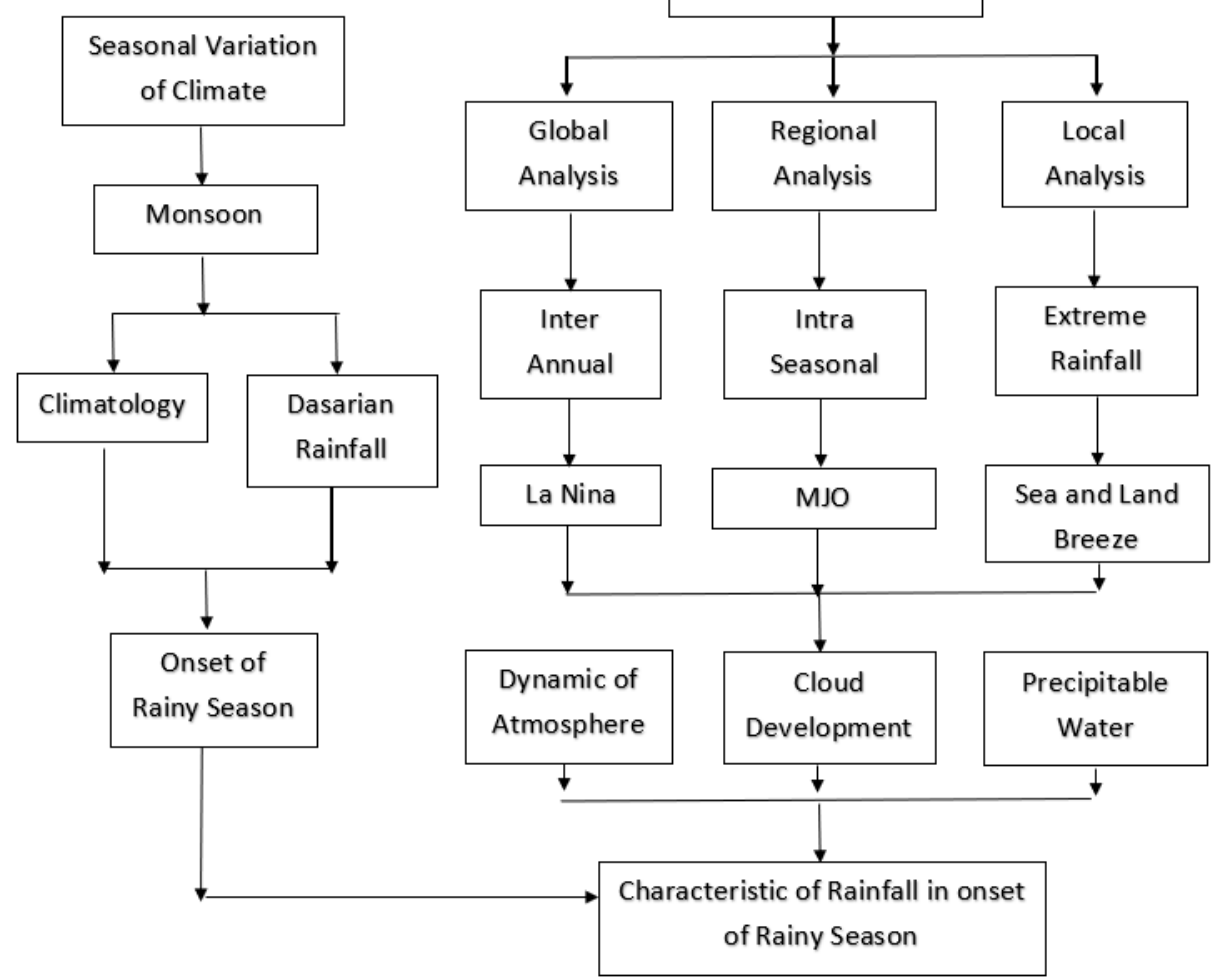

Figure 1. Seasonal and Non-seasonal Analysis

To get the characteristics of extreme rainfall at the beginning of the rainy season, the analysis is done for seasonal (monsoon) and non-seasonal variations. First, the analysis begins by looking at the extreme rainfall events at the beginning of the rainy season. The start of the season is determined at each rainfall observation station as in Figure 2. Determination of the start of the rainy season is obtained from dasarian [9]. The early period of the rainy season is marked by rainfall that fell 50 millimeters in a row in three days. From the results of the analysis of extreme rainfall at the beginning of the rainy season, then the nonseasonal variations in patterns that accompany the extreme rain events are sought. 


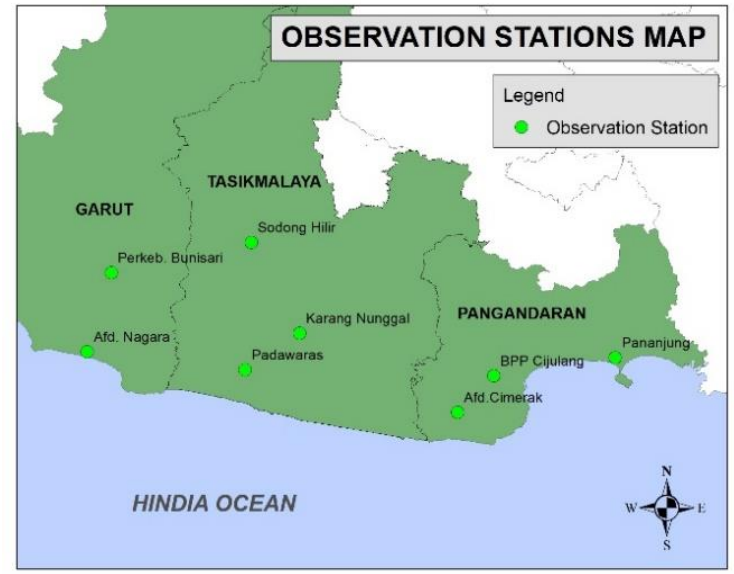

Figure 2. Observation Stations Map in South East West Java

Second, non-seasonal variations consist of inter-annual global patterns (La Nina-El Nino), intra-seasonal variation (MJO) and local pattern (of sea/land) and topography to get patterns of interaction between various phenomena at the beginning of the season. Furthermore, satellite cloud image analysis is performed to see cloud growth during extreme rain events along with La Nina, MJO, and local events. Atmospheric dynamics patterns (wind) are analyzed to get movement when extreme weather occurs and atmospheric physical dynamics analysis is done to obtain the potential for water vapor in the atmosphere. From the analysis of extreme rainfall events at the beginning of the season together with non-seasonal variations, we can conclude the causes of extreme rainfall events. Analysis of intra-seasonal atmospheric circulation was carried out to see the events in which conditions occur in active and inactive phases. The MJO phase consists of phases from phase one to phase eight, that is phases one and two are on the west of the Indian Ocean, phase three is on the east of the Indian Ocean, and phase four is on the maritime continent. The propagation of MJO one occurs through phase eight [23]. The MJO phase occurs in quadrant 1 in phase 1, 2 (East Africa), quadrant 2 in phase 3, 4 (Indian Ocean), quadrant 3 in phase 5, 6 (Maritime continent) and quadrant 4 in phase 7,8 (West and Middle Pacific Ocean).

To determine the MJO phase index, the researchers calculated the RMM1 and
RMM2 (Real-time Multivariate). This is also be done to determine the phase in 4 quadrants. In the negative phase of RMM1 and negative phase of RMM2 in quadrant three (Indian Ocean), it is shown to have strong amplitude if it is outside the circle box, and proven to be weak if it is inside the circle box [23].

Lastly, analysis of the available water vapor at the atmosphere was done by using precipitable water data. From these parameters, the identification of physical and dynamic factors can be used as an initial indicator of extreme rainfall in the rainy season.

\section{RESULTS AND DISCUSSION}

Extreme rainfall occurred at the beginning of the rainy season in 2016, 2017 and 2018 in most of the regions in Java Island. The rainfall recorded on September 16 was observed spatially from 21 millimeters/day to $126 \mathrm{~mm} /$ day with dominant rainfall $>50 \mathrm{~mm} /$ day. On the 6th of October 2019, rainfall event fell in the range of 24-208 $\mathrm{mm} /$ day, and between 48 and $400 \mathrm{~mm} /$ day on the 5 November 2018 event. Consecutive daily rainfall on 17/19/2016, 7/10/2017, and 5/11/2018 are Pangandaran (93; 208; $203 \mathrm{~mm})$, Cijulang (56; 115; $201 \mathrm{~mm})$, Cimerak (48; 68.5; 136 $\mathrm{mm})$, Sodong Hilir (126; 43; $107 \mathrm{~mm}$ ), Cipatujah (48; 27; $48 \mathrm{~mm}$ ) Karangnunggal $(-; 101 ; 400 \mathrm{~mm})$ and Cibalong $(21 ; 24 ; 110$ $\mathrm{mm})$, The most severe event occurred on November 5, 2018. These extreme rainfall events occurred in the rainy season onset as a monsoonal rainfall [8]. The rainy season onset usually begins from north to south and from west to east, zonally [24].

The rainy season onset usually starts from the dasarian III of September (Table 1). The onset of rainy season analysis showed that the beginning of the rainy season was in dasarian II of August in 2016. While in 2017 it was in September dasarian III, and October dasarian III for 2018. The starting time of the rainy seasons' onset in these three consecutive years experienced extreme precipitation events, which is different from the usual pattern or normal climatological 
pattern. The seasonal onset indeed fluctuates around its normal, sometimes it comes late or too early compared to the average event. Generally, the late (earlier) start of the season is closely related to El Nino [25].

In the maritime continent, the onset of the rainy season is mostly related with the activation of the westerly monsoon winds. The westerly monsoon wind that penetrated at the beginning of November 2018 indicated that the easterly monsoon wind was still strongly blowing from the Australian continent, while the westerly monsoon wind was weak even after the usual climatological onset of the rainy seasons (Figure 3). In contrast, monsoon circulation on September 16th, 2016 was dominated by atmospheric disturbance from the tropical storms "Meranti" which became a strong convection region. Meanwhile on October 6th, 2017 no tropical storm was seen.

On November 5th, 2018 the synoptic atmospheric circulation indicated a pattern of low-pressure area in the West Sumatra region (not shown). This low-pressure cell region generated potential atmospheric instabilities that favor cloud growth. Meanwhile, northwesterly winds were restrained by vortices in the West Indian Ocean in Sumatra and Kalimantan. The weakening of the wind speed in the southern part of Java also caused convergence in the Southern region of Java.

\section{The Linkages of Extreme Rainfall with Inter-annual and Seasonal Climate Variations}

Non-seasonal variation climate factor that causes rainfall variability is ENSO (La Nina and El Nino). La Nina causes rainfall in the maritime continental region to increase, while El Nino reduces rainfall [26]. Spatial correlation between PW and Nino regions shows that the western part of Indonesia is strongly correlated with Nino 3.4 (Figure 4). Based on the ENSO analysis using the Nino Index of 3.4, it was found that PW in the southeastern West Java region decreases when the sea level temperatures in Nino 3.4 increases, however PW in the western maritime continent is increased.

Table 1. Rainy season onset on Tasikmalaya and surroundings (Source: Bogor Climatology Station) Information: - means no data

\begin{tabular}{|c|c|c|c|c|c|c|c|c|c|}
\hline \multirow[b]{2}{*}{$\begin{array}{c}\text { Observatio } \\
\text { n Station }\end{array}$} & \multirow[b]{2}{*}{ District } & \multicolumn{2}{|c|}{ Climatology } & \multicolumn{2}{|c|}{2016} & \multicolumn{2}{|c|}{2017} & \multicolumn{2}{|c|}{2018} \\
\hline & & $\begin{array}{l}\text { Onset of } \\
\text { Dry } \\
\text { Season }\end{array}$ & $\begin{array}{c}\text { Onset } \\
\text { of } \\
\text { Rainy } \\
\text { Season }\end{array}$ & $\begin{array}{l}\text { Onset of } \\
\text { Dry } \\
\text { Season }\end{array}$ & $\begin{array}{c}\text { Onset } \\
\text { of } \\
\text { Rainy } \\
\text { Season }\end{array}$ & $\begin{array}{c}\text { Onset } \\
\text { of Dry } \\
\text { Season }\end{array}$ & $\begin{array}{l}\text { Onset of } \\
\text { Rainy } \\
\text { Season }\end{array}$ & $\begin{array}{l}\text { Onset } \\
\text { of Dry } \\
\text { Season }\end{array}$ & $\begin{array}{c}\text { Onset of } \\
\text { Rainy } \\
\text { Season }\end{array}$ \\
\hline Pananjung & Pangandaran & JUL III & SEP III & JUN III & AUG II & MAY I & SEP III & MAY I & OCT III \\
\hline $\begin{array}{c}\text { Afd. } \\
\text { Cimerak }\end{array}$ & Cimerak & JUL III & SEP III & JUN III & AUG II & MAY I & SEP III & MAY I & OCT III \\
\hline Padawaras & Cipatujah & JUL III & SEP III & JUN III & AUG II & MAY I & SEP III & MAY I & OCT III \\
\hline $\begin{array}{c}\text { Afd. } \\
\text { Nagara }\end{array}$ & Cibalong & JUL III & SEP III & JUN III & AUG II & MAY I & SEP III & MAY I & OCT III \\
\hline $\begin{array}{l}\text { Perkeb. } \\
\text { Bunisari }\end{array}$ & Cisompet & JUL III & SEP III & JUN III & AUG II & MAY I & SEP III & MAY I & OCT III \\
\hline $\begin{array}{c}\text { BPP } \\
\text { Cijulang }\end{array}$ & Cijulang & JUN I & SEP III & JUN I & - & MAY I & SEP III & MAY I & OCT III \\
\hline $\begin{array}{l}\text { Sodong } \\
\text { Hilir }\end{array}$ & Sodong Hilir & JUN I & SEP III & JUN I & - & MAY I & SEP III & MAY I & OCT III \\
\hline $\begin{array}{c}\text { Karang } \\
\text { Nunggal }\end{array}$ & $\begin{array}{c}\text { Karang } \\
\text { Nunggal }\end{array}$ & JUN I & SEP III & JUN I & - & MAY I & SEP III & MAY I & OCT III \\
\hline
\end{tabular}

The analysis of sea surface temperature showed that the La Nina Index was negative in 2016 and 2017. This climate anomaly (La Nina) caused the addition of water vapor in the maritime continent [27]. In contrast to 2018, the index value showed a positive value (El Nino) in November 2017 and 2018 [21]. In these periods, no global factors affected Indonesia; there was no increase in rainfall at the start of the rainy season in 2018. ENSO with anomaly that indicated anomalous SST Nino of 3.4 index 
explains most of the variability in the onset of the rainy season in Java [28]. During the El Nino and DM + events, the rainfall distribution pattern in Jakarta had a similar pattern with ones occur on June, July, August (JJA) and September, October and November (SON). The difference was that while the amount of the rainfall in SON and JJA decreased, the amount of the rainfall in DJF and MAM increased [29].

Another factor that caused the addition of water vapor in the maritime continent atmosphere is MJO. When the MJO is active, it can increase the water vapor levels in the maritime continent. MJO propagation on September $15^{\text {th }}-17^{\text {th }} 2016$ showed that it was still in phase 4 (in the maritime continent), and this impacted the addition of water vapor in that period. It was recorded in phase $3-4$ on October $5^{\text {th }}-7^{\text {th }}$, therefore clouds increased with low amplitude $(<1.0)$. MJO was in phase 1 on November $1^{\text {st }}$, then moved to phase 2 and 3 on November $2^{\text {nd }}, 2019$ in the Indian Ocean and near the central region of the maritime continent as shown in Table 2. This triggered a potential for water vapor. The MJO index was shown as negative values in the index (phase) 2 and 3 (Table 3). The index showed positive values in phase 4 for events from $15^{\text {th }}-20^{\text {th }}$ September 2016. Negative index values were shown in phases 2 and $3\left(5^{\text {th }}\right.$ $10^{\text {th }}$ October 2017) and on November $4^{\text {th }}-$ $9^{\text {th }}, 2$ 2018. In short, negative MJO index indicated an increase in clouds (rainfall).

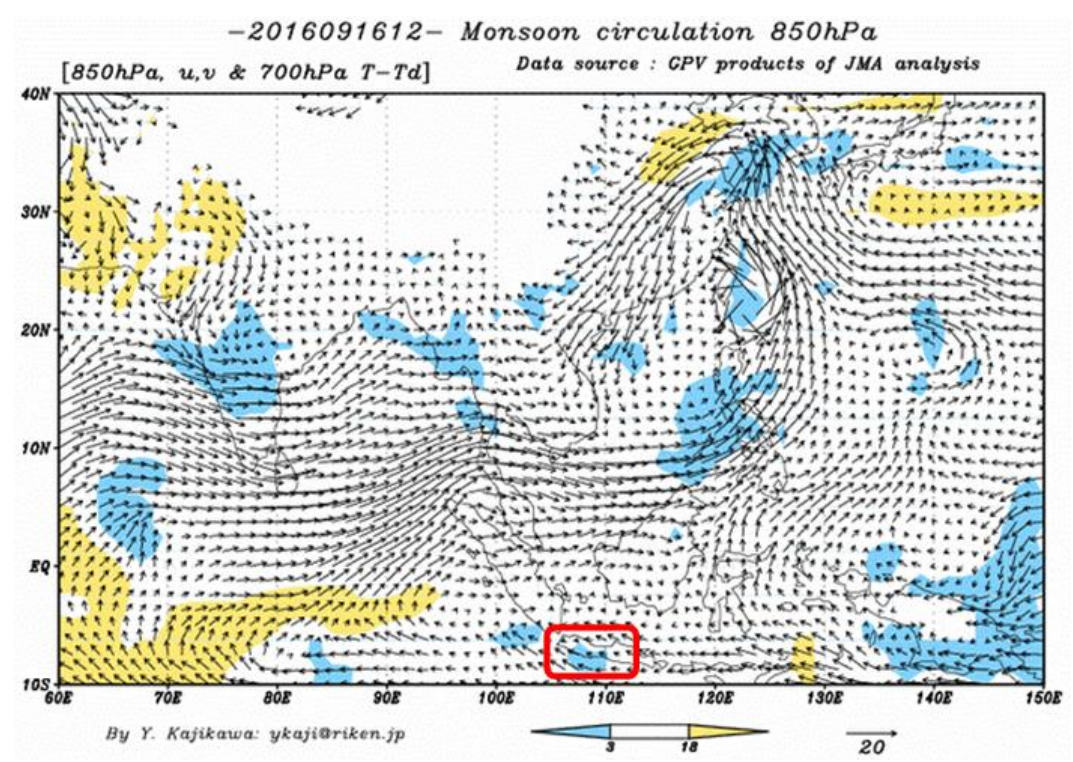

Figure 3. Monsoon Wind Pattern and Humidity (T-Td) on September $16^{\text {th }} 2017$, October $6^{\text {th }} 2017$, and November $5^{\text {th }}$ 2018, ADPRC (red box Color, research location) [18]

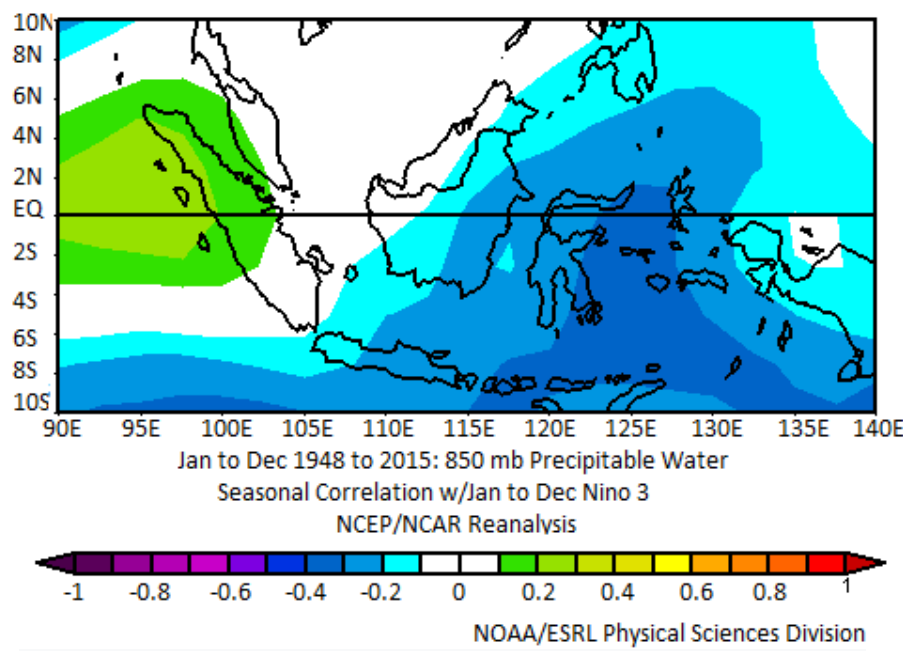

Figure 4. Correlation Nino 3.4 with Precipitable Water [20] 
Based on the characteristics of the $\mathrm{MJO}$, the water vapor potential can be analyzed. The rainfall occurrence depends on the availability or potential of water vapor in the atmosphere. Precipitable water pattern in southeast of West Java 100-110 E, $5-10 \mathrm{~S})$ on September $10^{\text {th }}-20^{\text {th }}, 2016$ was more than $50 \mathrm{~kg} / \mathrm{m}^{2}$, which has the same pattern with precipitable water on October $5^{\text {th }}, 2017$. Furthermore, the water vapor pattern showed an increase in the atmosphere on November $1^{\text {st }}$ in the range of $50 \mathrm{~kg} / \mathrm{m}^{2}$ and then gradually increased to be around $60 \mathrm{~kg} / \mathrm{m}^{2}$ on November $6^{\text {th }}, 2019$ as shown in Figure 5.
Table 2. MJO Index in Phase 2 to 4 (100E - 140E)

[20]

\begin{tabular}{cccc}
\hline \multirow{2}{*}{ Date } & INDEX 2 & INDEX 3 & INDEX 4 \\
\cline { 2 - 4 } & 100 E & 120 E & 140 E \\
\hline 20150915 & - & - & 0.49 \\
20150920 & - & - & 0.57 \\
20171005 & -0.74 & -0.8 & -0.69 \\
20171010 & -1.36 & -1.5 & -2.1 \\
20181104 & -1.55 & -1.1 & - \\
20181109 & -1.13 & -1.13 & - \\
\hline
\end{tabular}

Table 3. Madden Julian Oscillation Index in 2016, 2017, and 2018 on The Extreme Condition [19]

\begin{tabular}{ccccc}
\hline Year & RMM1 & RMM2 & Phase & Amplitude \\
\hline $15 / 09 / 2016$ & 1.7 & -0.7 & 4 & 1.84 \\
$16 / 09 / 2016$ & 1.7 & -0.5 & 4 & 1.74 \\
$17 / 09 / 2016$ & 1.5 & -0.5 & 4 & 1.62 \\
$05 / 10 / 2017$ & -0.2 & -0.7 & 2 & 0.71 \\
$06 / 10 / 2017$ & 0.2 & -0.6 & 3 & 0.64 \\
$07 / 10 / 2017$ & 0.8 & -0.5 & 4 & 0.95 \\
$04 / 11 / 2018$ & -0.5 & -1.4 & 2 & 1.52 \\
$05 / 11 / 2018$ & -0.1 & -1.5 & 2 & 1.45 \\
$06 / 11 / 2018$ & 0.3 & -1.6 & 3 & 1.66 \\
\hline
\end{tabular}

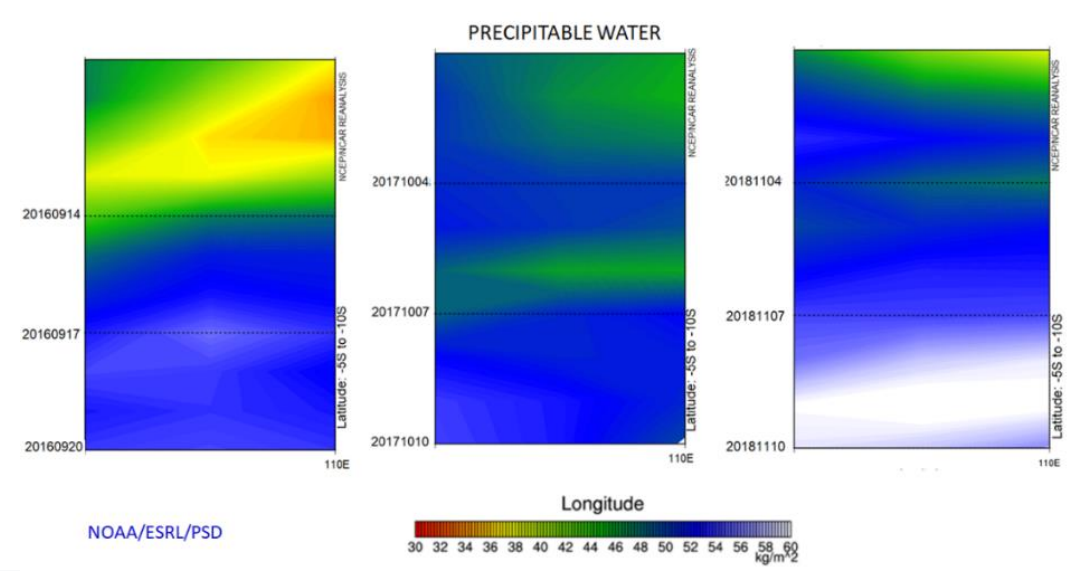

Figure 5. Hovmoller Diagram for Temporal variation of Mean Daily of Precipitable Water (100-110 E) in Garut, Tasikmalaya, and Pengandaran on (a) September $6^{\text {th }}, 2016$, (b) October $6 t^{\text {th }}, 2017$, and (c) November $5^{\text {th }}, 2018$, NOAA [20]

The correlation between the rainfall and the water vapor indicated that the characteristics of the physical conditions of the atmosphere contained enough water vapor to become the rainfall in the Tasikmalaya region on November $5^{\text {th }}$. The increased water vapor originated from the southern Indian Ocean in West Java and local water vapor due to high mountainous geographical conditions. In the western maritime continent, convection variability occurs due to synoptic patterns. The effect of MJO also influences convection, especially the daily cycle of weak synoptic influences. Other research reported MJO to also affect Tangerang region (northern of Banten) on the local scale weather conditions [30]. 


\section{Characteristics of Clouds during Extreme Rainfall}

There were differences in the characteristics of heavy rainfall at the beginning of the season on September 16th, 2016, October 6th, 2017, and November 5th, 2018 as shown in Figure 6. Based on the global analysis, atmospheric disturbances in 2016 tropical cyclones also occurred at the same time of the active MJO and La Nina, which caused the cloud patterns that generally appear as mesoscale clouds called MCS (Mesoscale Convective System). The influence of large-scale circulation anomalies and thermodynamic structures affect the beginning of the rainy season [31]. The evolution of Monsoon Onset is associated with atmospheric and oceanic processes that affect atmospheric convection and circulation processes [32].

MCS (Mesoscale Convective System) is a convective cloud storm that occur in response to the instability of a convective process, which combines a single cloud system that causes rainfall with a wide range of rainfall areas [33]. The second general pattern is the La Nina and MJO phases. The cloud growth in southern West Java on September $16^{\text {th }}, 2016$ showed that cloud growth started at 16.00 WIB (Local Time), then developed at 19.00 WIB until it reached the mature stage at 22.00 WIB to $23.00 \mathrm{WIB}$, and then decayed before morning at 04:00 WIB. This case also appeared on October $6^{\text {th }}$, 2017 when La Nina and MJO were active. It was different from November $6^{\text {th }} 2018$ where El Nino and MJO were active (Figure 7).

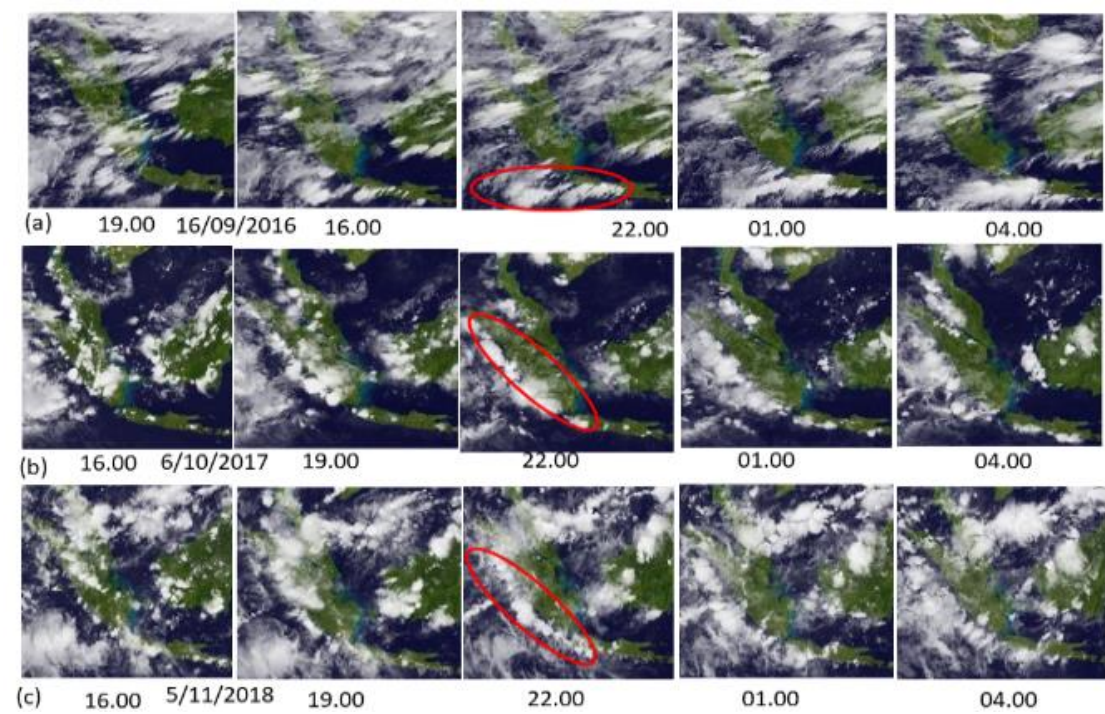

Figure 6. Satellite Imagery at 22:00 - 24:00 WIB (Local Time) on (a) September $16^{\text {th }}, 2016$ (b) October $6^{\text {th }}, 2017$ (c) November $5^{\text {th }}, 2018$ [22]
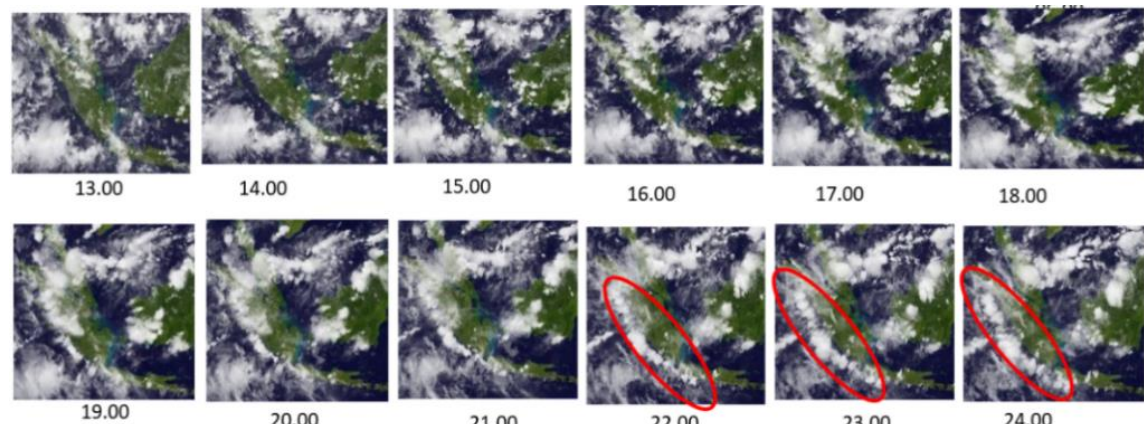

18.00

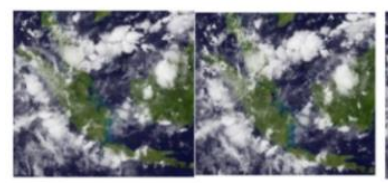

01.00

02.00

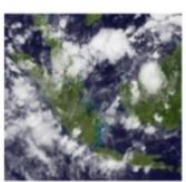

03.00
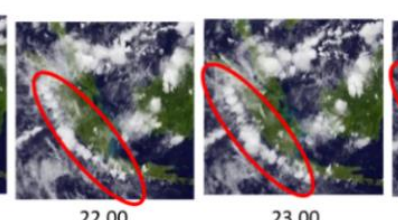

23.00

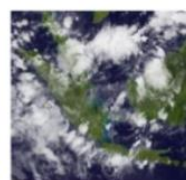

04.00

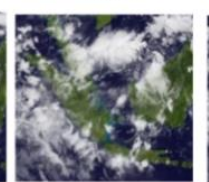

05.00

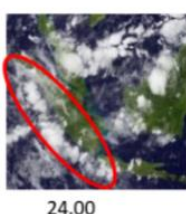

Figure 7. Cloud Growth When El Nino Happened on November $5^{\text {th }}, 2018$ in Local Time [22] 
As shown in the development of the MCS cloud cluster on November $5^{\text {th }}$, MCS clouds appeared in the ocean and moved ashore, and finally appeared in southern West Java at 16.00 WIB (local time). It reached its peak at 22.00 WIB - 24.00 WIB with a belt of clouds along the west coast of Sumatera to the south coast of West Java and decayed before $04.00 \mathrm{WIB}$. The dominance of beach convection pattern (MCS) in percentage $(\%)$ showed that MCS events in Indonesia as the maritime continent was $42.32 \%$ on land, $31.23 \%$ in the ocean, and $26.46 \%$ on the coastal area [34].

The cloud pattern showed the growth of clouds on the coast of the south of West Java region at 22.00 WIB - 24.00 WIB, and reached the peak with the initial cluster of meso-scale (diameter> 100 kilometers). The clouds were growing on the coast and then started to penetrate the mainland. This MCS cloud type often occurs in the continental maritime region. When the coast is getting cooler, the warm air masses of the Indian Ocean cool down and condense, which then forming clouds on a wide scale.

This type of cloud is from the convective cloud (cumulonimbus) and the rainfall characteristic is the shower type (large water droplets). Sea wind patterns (strong local) generally penetrate the land with a distance of $60-80$ kilometers from the coastline [35]. The northern Tasikmalaya region consists of high mountains hence the mass of water vapor from the Indian Ocean is restrained and forced to rise in the orographic rain. Strengthening rain from the main winds and sea breezes causes a significant increase in the water vapor. Diurnal cycles that occur in the rainy season in Java and Bali are caused by the differences in the temperature gradients of the coast and land [36].

\section{Sea Surface Temperature Characteristics}

The characteristics of potential water vapor and clouds in September prior to the occurrence of heavy rains will indicate the cooling or heating pattern. The contributing factor is the increase in the sea surface temperatures caused by the shift in the rainfall in the early monsoon [37]. Sea surface temperatures in August 2016 around the southern part of West Java showed the higher temperatures $\left(>1.0^{\circ} \mathrm{C}\right)$ than the average temperature in August (1995-2015). This condition coincided with La Nina (warming in the maritime Continent). The same condition occurred in September 2017 in which the sea surface temperature was hotter than the average temperature, therefore it contributed to the increase of water vapor (cloud growth) in October 2017.

Different conditions occurred in October 2018 when the sea surface temperature was cooler due to the La Nina phenomenon. During this period, an increase in water vapor occurred due to the phenomenon of strong MJO and local circulation (convection on the coast), as seen from the movement of local clouds along the West coast of Sumatra to West Java (Figure $6)$. This condition became the source of water vapor in September and triggered the increase of cloud growth in September 2016.

\section{Topography Effects}

Figure 8 shows clouds patterns along the south eastern coastline of West Java influenced by the characteristics of the coast and mountains. Clouds are generally growing in the next part of the coast by the sea-breeze and then pushed towards the mountainous region. This orographic cloud pattern characterizes the climatology of the regions of Garut, Tasikmalaya, and Pangandaran. The topographic characteristics of the North Garut Regency consist of the highlands and mountains, while the southern part is the coast region [38], the earth's surface shape of Tasikmalaya. The north is a plateau region and the southern part is a lowland region [39]. Meanwhile, the area of the northern region is the southern mountains which are the coastline [40]. Climatological vector wind patterns showed southeasterly winds in September, October, and November (Figure 9). This pattern indicated that the southeasterly wind entered the region, forced it to ride to the mountains in the northern part of Garut, Tasikmalaya, and 
Pangandaran, and made the great convection rainfall type [41]. over the mountainous areas as orographic
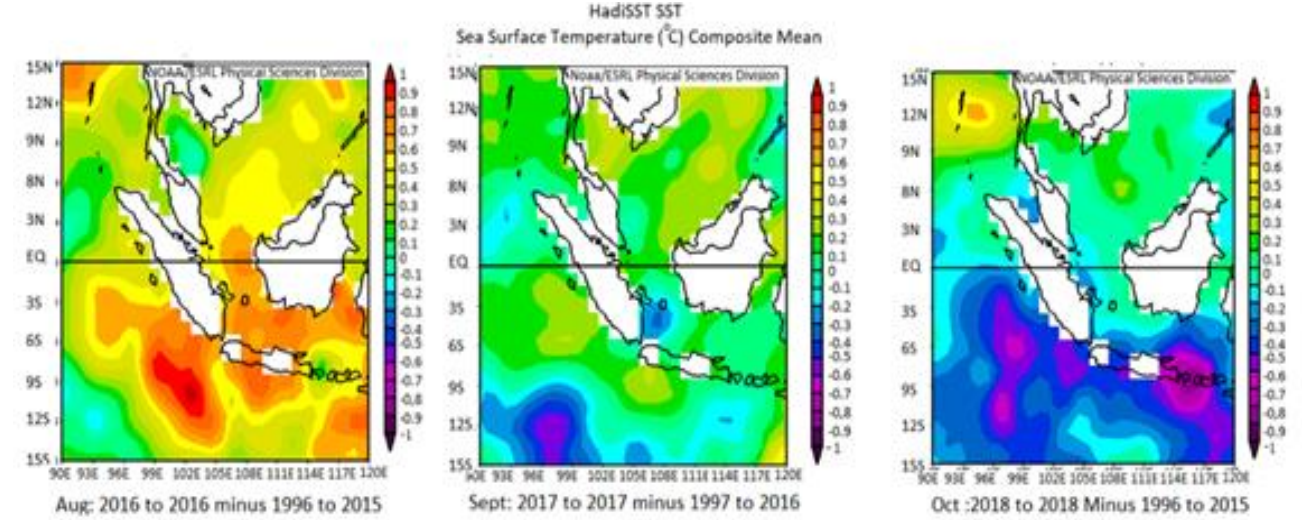

Figure 8. Sea Surface Temperature/SST (1 Month Lag), on (a) September $16^{\text {th }}, 2016$ (SST of August 2016 Minus Monthly Average of August), (b) October 6 ${ }^{\text {th }}, 2017$ (SST of September 2017 Minus Monthly Average of September), (c) November $5^{\text {th }}, 2018$ (SST of October 2018 Minus Monthly Average of October) [20]

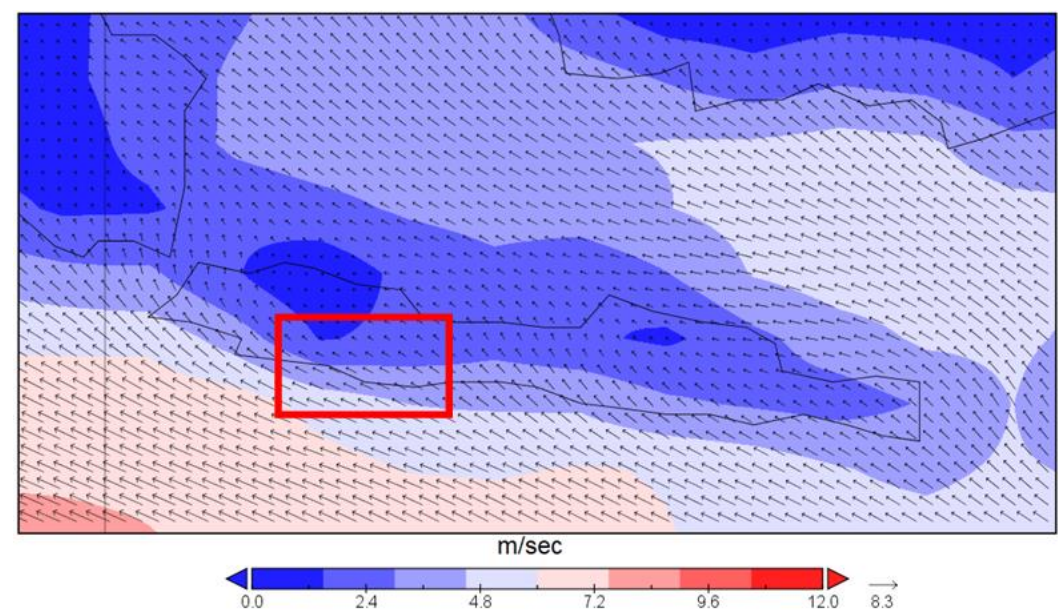

Figure 9. Seasonal Average of Wind Vector on September, October, and November (SON) (1989 - 2018) (Redbox Color: Research Location)

Table 4. Effect of non-seasonal variation and tropical disturbance on southern West Java Information: v means take effect, - means no effect

\begin{tabular}{cccccc}
\hline & \multicolumn{5}{c}{ Non-seasonal variation } \\
\cline { 2 - 6 } Date & El & La & MJO & Local & Tropical \\
& Nino & Nina & & Circ. & storm \\
\hline $16 / 9 / 16$ & - & V & - & - & V \\
$6 / 10 / 17$ & - & V & v & v & - \\
$5 / 11 / 18$ & v & - & v & v & - \\
\hline
\end{tabular}

The effects of non-seasonal variation and tropical storms are summarized in Table 4. This research contributed to the new knowledge in meteorology in regards to the weather anomaly in onset monsoon which generally comprise extreme weather in the peak of rainfall in the rainy seasons.
From the analysis, we found that extreme precipitation during the transition period in the Southeast West Java region was mainly caused by a non-seasonal climate variation. The non-seasonal variations that have been revealed in the analysis are intra-seasonal MJO activity, an inter-annual phenomenon (La Nina/ El Nino), tropical storm and local circulation. The local circulation plays an important role in the areas of Southeast West Java since most of the region is featured by mountainous areas. Over the mountainous areas, the clouds grow during the day and develop into great convection clouds in the afternoon by its topographic effects and strengthen the rainfall intensity. 
The study of global and local circulations for extreme rainfall in the north of West Java only focusing MJO $[42,43]$. They focus in the global bone parameters to identify the extreme rainfall while in Java Island rainfall variability determined by interaction ENSO, monsoon and diurnal cycle in Java Island [44]. In this study is more comprehensive, the extreme rainfall events occur due to climate phenomena which occur simultaneously at the beginning of the rainy season.

\section{IV.CONCLUSION}

The dominant factor causing the three extreme rainfall cases occurred in the southeast West Java at the beginning of the rainy season is the non-seasonal variations that happen individually or through the joint climate phenomenon that occur simultaneously. Those are the MJO as intra-seasonal variability and inter-annual phenomena; intra-seasonal (La Nina/ El Nina); tropical storm; and local circulation. The local circulation is mainly generated by topographic effects which strengthen rainfall intensity over mountainous areas. This mountainous rainfall pattern can be identified where the clouds grow during the day and develop into convection clouds in the afternoon over the mountains areas of Southeast West Java. However, although conclusions can be drawn in this research, the findings are limited by its few cases. Thus, forthcoming research is needed to achieve more evidence and satisfy the statistical consideration.

\section{ACKNOWLEDGMENT}

Authors would like to thank the Research and Community Service Unit of the School of Meteorology, Climatology and Geophysics who have supported the research (Reference letter : SK.055/VII/2019).

\section{REFERENCES}

[1] Badan Pusat Statistik Jawa Barat. Current Statistidal Indicator of West Java Province (Indikator Statistik Terkini Provinsi Jawa Barat); 2019. Available from: https://jabar.bps.go.id/publication/2019/08/0 8/3515121f56b72b372bb07111/indikator-sta tistik-terkini-provinsi-jawa-barat-2019--edisi -juli.html [accessed 10 June 2020].

[2] Surmaini E and Faqih A. Kejadian Iklim Ekstrem dan Dampaknya Terhadap Pertanian Tanaman Pangan di Indonesia. Jurnal Sumberdaya Lahan. 2016; 10(2): 115-128. Available from:

http://ejurnal.litbang.pertanian.go.id/index.p hp/jsl/article/view/7031.

[3] Siswanto, Oldenborgh GJV, Schrier GVD, Lenderink G, and Hurk BVD. Trends in High-daily Precipitation Events in Jakarta and the Flooding of January 2014. Bulletin American Meteorology Society. 2015; 96(12): S131-S135. DOI:

https://doi.org/10.1175/BAMS-D-15-00128. 1.

[4] Siswanto, Schrier GVD, Oldenborgh GJV, Hurk BVD, Aldrian E, Swarinoto Y, Sulistya W, and Sakya AE. A Very Unusual Precipitation Event Associated with the 2015 Floods in Jakarta: An Analysis of the Meteorological Factors. Weather and Climate Extremes. 2017; 16: 23-28. DOI: https://doi.org/10.1016/j.wace.2017.03.003.

[5] Sudewi RSS, Sasmito A, and Kurniawan R. Identifikasi Ambang Batas Curah Hujan Saat Kejadian Banjir di Jabodetabek: Studi Kasus Banjir Jakarta Tanggal 09 Februari 2015. Jurnal Meteorologi dan Geofisika. 2015; 16(3): 209-215. DOI:

http://dx.doi.org/10.31172/jmg.v16i3.315.

[6] Nicholson SE. ITCZ and the Seasonal Cycle Over Equatorial Africa. Bulletin of the American Meteorological Society. 2018; 99(2): 337-348. DOI:

https://doi.org/10.1175/Bams-D-16-0287.1. 
[7] Mulyana E, Prayoga MBR, Yananto A, Wirahma S, Aldrian E, Harsoyo B, Seto TH, and Sunarya Y. Tropical Cyclones Characteristic in Southern Indonesia and the Impact on Extreme Rainfall Event. MATEC Web of Conferences. 2018: 229: 02007. DOI: https://doi.org/10.1051/matecconf/20182290 2007.

[8] Aldrian E and Susanto RD. Identification of Three Dominant Rainfall Regions within Indonesia and Their Relationship to Sea Surface Temperature. International Journal of Climatology. 2003; 23(12): 1435-1452. DOI: https://doi.org/10.1002/joc.950.

[9] Badan Meteorologi Klimatologi dan Geofisika 2019. Seasonal Prediction for Rainy Season 2019 (Prakiraan Musim Hujan 2019). Available from: https://www.bmkg.go.id/iklim/prakiraan-mu sim.bmkg [accessed 10 June 2020].

[10] Yulihastin E, Risyanto, and Fathrio I. Seasonal Migration of the ITCA over Maritime Continent Based on TRMM Satellite. Proceeding of International Symposium on the $10^{\text {th }}$ Anniversary of the Equatorial Atmosphere Radar (EAR). Jakarta; 2011.

[11] Trismidianto and Satyawardhana $H$. Mesoscale Convective Complexes (MCCs) over the Indonesian Maritime Continent during the ENSO Events. IOP Conference Series: Earth and Environmental Science. 2018; 149: 012025. DOI: https://doi.org/10.1088/1755-1315/149/1/01 2025.

[12] Zhang Q, Gu X, Li J, Shi P, and Singh VP. The Impact of Tropical Cyclones on Extreme Precipitation over Coastal and Inland Areas of China and Its Association to ENSO. Journal of Climate. 2018; 31(5): 1865-1880. DOI:

https://doi.org/10.1175/JCLI-D-17-0474.1.

[13] Salahuddin A and Curtis S. Evolution of Mesoscale Convective Systems and Its Relationship with the Madden-Julian
Oscillation in the Indo-Pacific Region. The Open Atmospheric Science Journal. 2009; 3: 158-171. DOI:

http://dx.doi.org/10.2174/187428230090301 $\underline{0158}$.

[14] Mcgregor GR and Nieuwolt S. Tropical Climatology: An Introduction to the Climates of the Low latitudes. US: Wiley; 1998.

[15] Aldrian E. Spatial Patterns of Enso Impact on Indonesian Rainfall. Jurnal Sains \& Teknologi Modifikasi Cuaca. 2002; 3(1): 5-15. Available from: http://ejurnal.bppt.go.id/index.php/JSTMC/a rticle/view/2154 [accessed 26 April 2019].

[16] Freitas ACV, Aímola L, Ambrizzi T, and Oliveira CPD. Extreme Intertropical Convergence Zone Shifts over Southern Maritime Continent. Atmospheric Science Letters. 2016; 18(1): 2-10. DOI: https://doi.org/10.1002/asl.716.

[17] Wu P, Ardiansyah D, Yokoi S, Mori S, Syamsudin F, and Yoneyama K. Why Torrential Rain Occurs on the Western Coast of Sumatra Island at the Leading Edge of the MJO Westerly Wind Bursts. SOLA. 2017; 13: 36-40. DOI: https://doi.org/10.2151/sola.2017-007.

[18] Asia-Pacific Data Research Center, Honolulu, Hawai, United States of America. Available from:

http://apdrc.soest.hawaii.edu/projects/monso on/as85/201609/2016091612as85.gif [accessed 26 April 2019].

[19] The Bureau of Meteorology, Australia. Madden-Julian Oscillation. Available from: http://www.bom.gov.au/climate/mjo/graphic s/rmm.74toRealtime.txt [accessed 26 April 2019].

[20] National Weather Service National Centers for Environmental Prediction Climate Prediction Center (NCEP). Available from: https://www.esrl.noaa.gov/psd/map/time_plo t/ [accessed 26 April 2019].

[21] National Weather Service National Centers for Environmental Prediction Climate 
Jurnal Penelitian Fisika dan Aplikasinya (JPFA), 2020; 10(2): 173-187

Prediction Center (NCEP). Cold and Warm

Episodes by Season. Available from: https://origin.cpc.ncep.noaa.gov/products/an alysis monitoring/ensostuff/ONI v5.php [accessed 26 April 2019].

[22] Kochi University. Weather Home. Available from

http://weather.is.kochi-u.ac.jp/index-e.html [accessed 26 April 2019].

[23] Wheeler MC and Hendon HH. An All-Season Real-Time Multivariate MJO Index: Development of an Index for Monitoring and Prediction. Monthly Weather Review. 2004; 132: 1917-1932. DOI: https://doi.org/10.1175/1520-0493(2004)132 \%3C1917:AARMMI\%3E2.0.CO;2.

[24] Giarno, Dupe ZL, dan Mustofa AM. Kajian Awal Musim Hujan dan Awal Musim Kemarau di Indonesia. Jurnal Meteorologi Dan Geofisika. 2012; 13(1): 1-8. DOI: http://dx.doi.org/10.31172/jmg.v13i1.113.

[25] Xavier PK, Marzina C, and Goswami BN. An Objective Definition of the Indian Summer Monsoon Season and a New Perspective on the ENSO-Monsoon Relationship. Quarterly Journal of the Royal Meteorological Society. 2007; 133: 749-764. DOI:

https://doi.org/10.1002/qj.45.

[26] Chang CP, Wang Z, Ju J, and Li T. On the Relationship Between West Maritim Continent Monsoon Rainfall and ENSO During Northern Winter. Journal of Climate 2004; 17(3): 665-672. DOI:

https://doi.org/10.1175/1520-0442(2004)017 \%3C0665:OTRBWM\%3E2.0.CO;2.

[27] Hendon HH. Indonesian Rainfall Variability: Impacts of ENSO and Local Air-sea Interaction. Journal of Climate. 2003; 16(11): 1775-1790. DOI:

https://doi.org/10.1175/1520-0442(2003)016 \%3C1775:IRVIOE\%3E2.0.CO;2.

[28] Rohmawati FY, Boer R, dan Faqih A. Prediksi Awal Musim Hujan Berdasarkan Indeks Variabilitas Iklim di Pulau Jawa.
Jurnal Tanah dan Iklim. 38(1): 35-42. Available from:

http://www.ejurnal.litbang.pertanian.go.id/in dex.php/jti/article/view/6247.

[29] Nuryanto DE. Karakteristik Curah Hujan Abad 20 di Jakarta Berdasarkan Kejadian Iklim Global. Jurnal Meteorologi dan Geofisika. 2013; 14(3): 139-147. DOI: http://dx.doi.org/10.31172/jmg.v14i3.165.

[30] Pramuwardani I, Hartono, Sunarto, and Sopaheluwakan A. The Influence of Madden Julian Oscillation on Local Scale Phenomena over Indonesia during the Western North Pacific and Australian Monsoon Phases. Forum Geografi. 2018; 32(2): 156-169. DOI: http://dx.doi.org/10.23917/forgeo.v32i2.622 6.

[31] Latif M and Syed FS. Determination of Summer Monsoon Onset and Its Related Large-Scale Circulation Characteristics over Pakistan. Theoretical and Applied Climatology. 2016; 125: 509-520. DOI: https://doi.org/10.1007/s00704-015-1530-y.

[32] Pai DS and Nair RM. Summer Monsoon Onset over Kerala: New Definition and Prediction. Journal of Earth System Science 2009; 118: 123-135. DOI: https://doi.org/10.1007/s12040-009-0020-y.

[33] Houze RA. Mesoscale Convective Systems. Review of Geophysics. 2004; 42(4): RG4003. DOI:

https://doi.org/10.1029/2004RG000150.

[34] Trismidianto. Characteristics of the Oceanic MCC, Continental MCC, and Coastal MCC Over the Indonesian Maritime Continent. IOP Conference Series: Earth and Environmental Science. 2018; 149: 012024. DOI:

https://doi.org/10.1088/1755-1315/149/1/01 2024.

[35] Hadi TW, Horinouchi T, Tsuda T, Hashiguchi $\mathrm{H}$, and Fukao S. Sea-Breeze Circulation over Jakarta, Indonesia: A Climatology Based on Boundary Layer Radar Observations. 
Jurnal Penelitian Fisika dan Aplikasinya (JPFA), 2020; 10(2): 173-187

Monthly Weather Review. 2002; 130(9): 2153-2166. DOI:

https://doi.org/10.1175/1520-0493(2002)130 \%3C2153:SBCOJI\%3E2.0.CO;2.

[36] Yamanaka MD. Physical Climatology of Indonesian Maritime Continent: An Outline to Comprehend Observation Studies. Atmospheric Research. 2016; 178-179: 231-259. DOI:

https://doi.org/10.1016/j.atmosres.2016.03.0 17.

[37] Tsai C, Behera SK, and Waseda T. Indo-China Monsoon Indices. Scientific Reports. 2015; 5: 8107. DOI: https://doi.org/10.1038/srep08107.

[38] Dinas Komunikasi dan Informatika Kabupaten Garut. Topografi; 2017. Available from:

https://www.garutkab.go.id/page/topografi [accessed 10 June 2020].

[39] Dinas Komunikasi dan Informatika Kabupaten Tasikmalaya. Kondisi Topografis; 2019. Avalaible from: https://tasikmalayakab.go.id/index.php/en/ho me/kondisi-topografis [accessed 10 June 2020].

[40] Dinas Komunikasi Informatika Statistik dan Persandian Kabupaten Pangandaran. Profil Kabupaten Pangandaran; 2019. Available from: http://web.pangandarankab.go.id/public/prof ile/profil-kabupaten-pangandaran [accessed 10 June 2020].

[41] Roe GH. Orographic Precipitation. Annual Review of Earth and Planetary Sciences. 2005; 33: 645-671. DOI:

https://doi.org/10.1146/annurev.earth.33.092 203.122541.

[42] Lestari S, King A, Vincent C, Karoly D, and Protat A. Seasonal Dependence of Rainfall Extremes in and Around Jakarta, Indonesia. Weather and Climate Extreme. 2019; 24: 100202. DOI:

https://doi.org/10.1016/j.wace.2019.100202.

[43] Wu P, Arbain AA, Mori S, Hamada JI, Hattori M, Syamsudin F, and Yamanaka MD. The Effects of an Active Phase of the Madden-Julian Oscillation on the Extreme Precipitation Event Over Western Java Island in January 2013. SOLA. 2013; 9: 79-83. DOI:

https://doi.org/10.2151/sola.2013-018.

[44] Qian JH, Robertson AW, and Moron V. Interactions Among ENSO, the Monsoon, and Diurnal Cycle in Rainfall Variability over Java, Indonesia. Journal of The Atmospheric Sciences. 2010; 67(11): 3509-3524. DOI: https://doi.org/10.1175/2010JAS3348.1. 